\title{
Cefepime neurotoxicity can mimic postanoxic coma with myoclonic status epilepticus
}

Nitin K. Sethi, MD, New York-Presbyterian Hospital: I read with interest the article by Hocker and Rabinstein ${ }^{1}$ in the December 2011 issue of Neurology ${ }^{\circledR}$ Clinical Practice. The authors report a post-coronary artery bypass graft patient with cefepime neurotoxicity mimicking postanoxic encephalopathy with postanoxic myoclonic status epilepticus. There was no surface EEG correlate to the patient's myoclonic jerks. In postanoxic myoclonus and myoclonic epilepsies there is a generalized spike wave or polyspike and wave surface EEG correlate to the patient's myoclonic jerks. The surface EEG correlate helps to distinguish cortical myoclonus, which may respond to anticonvulsants such as levetiracetam, clonazepam, and sodium valproate, from subcortical myoclonus, which may be of brainstem or spinal origin. Hence the title of the author's article is misleading. Seizures have been reported with cefepime neurotoxicity. ${ }^{2,3}$ The myoclonus in the author's patient was likely a part and parcel of toxic encephalopathy and not of cortical origin.

Disclosures: Dr. Sethi is an associate editor for The Eastern Journal of Medicine.

Correspondence to: sethinitinmd@hotmail.com

Authors Respond: Sara Hocker, MD, Alejandro Rabinstein, MD, Mayo Clinic, Rochester, MN: We agree with Dr. Sethi that the surface EEG often shows a correlate in the form of a burst of activity correlating with the clinical myoclonic event in the case of cortically generated myoclonus as is seen with anoxic status epilepticus. Our aim was to illustrate the semiologic rather than the electrographic similarity between the myoclonus in our patient and the pattern seen with anoxic status epilepticus and additionally to draw attention to the administration of cefepime as an etiology of, in this case, profound encephalopathy in clinical practice.

Disclosures: See original article for full disclosure list.

Correspondence to: Hocker.Sara@mayo.edu

Waldo Guerrero, University of Florida, Gainesville: A brain MRI would have been useful to evaluate for metabolic/structural insult to basal ganglia. ${ }^{1}$ It is possible that transient metabolic derangement of basal ganglia from hypotension or hypoxia reversed as these issues were corrected.

Disclosures: The author reports no disclosures.

Correspondence to: waldo.guerrero@neurology.ufl.edu

Authors Respond: Sara Hocker, MD, Alejandro Rabinstein, MD, Mayo Clinic, Rochester, MN: We appreciate the interest in our case and agree that transient lesions in the basal ganglia bilaterally could have caused some degree of encephalopathy and abnormal involuntary movements such as those seen in our patient. A noncontrast CT scan of the head was chosen over an MRI to rule out any major structural abnormality to account for her profound encephalopathy as she had a GFR of $32 \mathrm{~mL} / \mathrm{min} / 1.73 \mathrm{~m}^{2}$ and had tenuous hemodynamics less than 24 hours before the time of our evaluation requiring vasopressor support and bilevel ventilation in order to maintain adequate oxygenation. While an MRI may have demonstrated involvement of the basal ganglia providing an alternative explanation for her abnormal movements we would have expected a larger area of 
involvement likely including the thalami bilaterally to also account for her coma. Furthermore, if these lesions were indeed present, they would likely be picked up on CT scan, given that her symptomatology was progressive for 3 days prior to obtaining the study. Based on our experience, the clinical recovery began too rapidly for metabolic encephalopathies causing changes in the basal ganglia.

Disclosures: See original article for full disclosure list.

Correspondence to: Hocker.Sara@mayo.edu

1. Hocker S, Rabinstein AA. Cefepime neurotoxicity can mimic postanoxic coma with myoclonic status epilepticus. Neurol Clin Pract 2011;1:73-74.

2. Fishbain JT, Monahan TP, Canonico MM. Cerebral manifestations of cefepime toxicity in a dialysis patient. Neurology 2000;55:1756-1757.

3. Dixit S, Kurle P, Buyan-Dent L, Sheth RD. Status epilepticus associated with cefepime. Neurology 2000;54:2153-2155.

\section{CORRECTION}

Neurogenetics: Five new things

In the article "Neurogenetics: Five new things" by S. Jayadev et al. (Neurology ${ }^{\circledR}$ Clinical Practice 2011;1:41-48), there is an omission in figure 2, which should read "The copyright for this figure is held by the University of Washington.” The editorial staff regrets the omission.

\section{CORRECTION}

Treating patients with medically resistant epilepsy

In the article "Treating patients with medically resistant epilepsy" by Gregory L. Krauss and Michael R. Sperling (Neurology ${ }^{\circledR}$ Clinical Practice 2011;1:14-23), there is an error in the second to last line in table 3. "Corpus callosotomy (anterior 66\% to 80\%)" should be listed as another bullet point under treatment for "Severe symptomatic forms of epilepsy" below "Third-line adjunctive therapies." The publisher regrets the error. 


\title{
Neurology ${ }^{\circ}$ Clinical Practice
}

\author{
Cefepime neurotoxicity can mimic postanoxic coma with myoclonic status epilepticus \\ Nitin K. Sethi, Sara Hocker, Waldo Guerrero, et al. \\ Neurol Clin Pract 2012;2;3-4 \\ DOI 10.1212/CPJ.0b013e31824c7b90
}

This information is current as of March 16, 2012

$\begin{array}{ll}\begin{array}{l}\text { Updated Information \& } \\ \text { Services }\end{array} & \begin{array}{l}\text { including high resolution figures, can be found at: } \\ \text { http://cp.neurology.org/content/2/1/3.full.html }\end{array} \\ \text { References } & \begin{array}{l}\text { This article cites } 3 \text { articles, } 3 \text { of which you can access for free at: } \\ \text { http://cp.neurology.org/content/2/1/3.full.html\#\#ref-list-1 }\end{array} \\ \text { Permissions \& Licensing } & \begin{array}{l}\text { Information about reproducing this article in parts (figures,tables) or in } \\ \text { its entirety can be found online at: } \\ \text { http://cp.neurology.org/misc/about.xhtml\#permissions }\end{array} \\ \text { Reprints } & \begin{array}{l}\text { Information about ordering reprints can be found online: } \\ \text { http://cp.neurology.org/misc/addir.xhtml\#reprintsus }\end{array}\end{array}$

Neurol Clin Pract is an official journal of the American Academy of Neurology. Published continuously since 2011, it is now a bimonthly with 6 issues per year. Copyright Copyright $\odot 2012$ by AAN Enterprises, Inc.. All rights reserved. Print ISSN: 2163-0402. Online ISSN: 2163-0933.

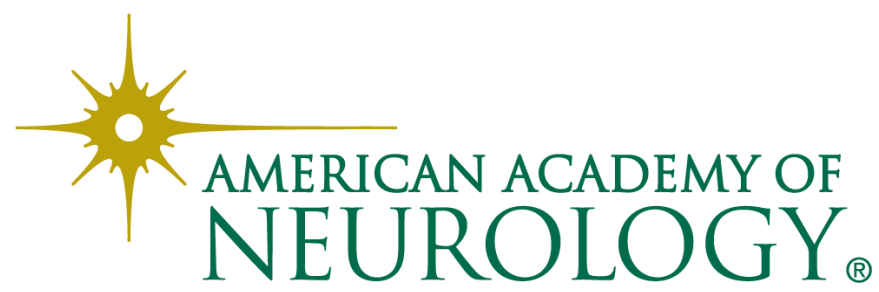

